\title{
correspondence
}

\section{Alaskan earthquake}

SIR,-The item on Alaskan earthquakes by P. J. Smith (7 July, page 12) is misleading-the point at issue is not the frequency of seismic events in Northern Alaska, but their magnitude.

The section of the pipeline of which he writes was required to be designed to withstand an earthquake of magnitude 5.5 without spillage; the federal requirements were only drawn up after extensive analysis by a variety of groups not depending solely on seismic data. Obviously these people appreciated that the absence of recorded activity was more apparent than real. I can see no reason to assert, as Smith does, that a report on the frequency of seismic events in the magnitude range 1 to 4 for a section designed to resist magnitude 5.5 shocks reveals an example of oversimplification through ignorance.

I might add that many crude oil pipelines around the world were built before good seismic data became available (for instance in Iran early in the century) and there is no record of any of them ever having ruptured as a result of an earthquake.

Yours faithfully,

$$
\text { F. G. LaRMinie }
$$

British Petroleum, London, UK

\section{China and scientific unions}

SIR,-In your editorial (28 July, page 283), you accuse The People's Republic of China of "trying to import" politics into the international scientific unions. You ignore the fact that politics must inevitably play a role in the unions as they are at present constituted. For example, how can a union, composed of member countries and financed by their governments, fail to consider the question of what is meant by a country?

In discussing Chinese representation in the unions one should remember that Taiwan has never been olaimed to be other than a province of China by the authorities either in Peking or Taipei. Thus recognising Taiwan as an independent country would place the international unions in the strange position of giving Taiwan a status not claimed for it by any international authority including the United Nations and UNESCO, or even by its own administration. Although this is a course of action that was taken by several of the unions (eg the International Astronomical Union in 1958), such a decision withdrew the right of the Academia Sinica in Nanking to represent a part of China which it had previously represented and in my view thereby often violated the statutes of the union.

Such actions took place during the fifties when a successful campaign was instigated by the US State Department to secure the membership of China in the unions for representatives of the Academia Sinica in Taipei. Often the Taiwanese applied and were admitted to membership of unions for which any relevant activity in Taiwan was miniscule or non-existent. The acquiescence of ICSU and its unions in this attempt to isolate the Chinese from the international scientific community is responsible for the bitterness with which many Chinese scientists still view ICSU and the insistence with which they demand that the previous decisions be reversed.

Yours faithfully,

Leiden, Netherlands

$$
\text { GeORGe K. Miley }
$$

\section{No arms link}

SIR,-In your 'in brief' column (18 August, page 582) you state that "African National Congress officials are reported as saying that 15 German research institutions, including the Max Planck Institute for Nuclear Physics at Heidelberg, have contributed to South Africa's arms programme". We would like to state that the Max Planck Institute for Nuclear Physics is devoted only to basic research in the physics of nuclear structure and nuclear reactions. This research is completely unrelated to arms production.

Yours faithfully, U. SCHMIDT-ROHR

Max Planck Institute for

Nuclear Physics,

Heidelberg, West Germany

\section{Sunflower: a misnomer?}

Sir,--It is commonly believed that the movement of the sunflower (Helianthus annuus) is a typically heliotropic movement and that with a certain lag, heads follow the path of the sun across the skies in the wake of its daily east-west movement. Observations on a field of sunflowers growing in the essentially cloudless Mediterranean summer climate at the Ma'abaroth kibbutz settlement in the Sharon plain in Israel reveal that during the night the extent of sunflower head movement is more rapid than during the day.

At dusk all heads do indeed face west, but by 2 am, before any trace of light on the horizon, all heads had reverted to an east facing position. Calculated average velocity of movement during daylight is $\pm 13^{\circ}$ per $\mathrm{h}$ as against $\pm 26^{\circ}$ per $h$ in the dark.

Furthermore, when complete rotation towards the east had occurred, by 2 am the heads were held at $\sim 40^{\circ}-45^{\circ}$ above the horizontal and upon the appearance of the sun heads 'nodded' eastwards to the extent of a further $15^{\circ}$, as if slightly bowing to greet the rising sun, and only subsequently started their daily journey westwards.

These observations suggest an endogenous 'spring' mechanism, apparently wound up by the sun and released in the dark or light period. The fact that the night movement is twice as rapid as that of the day seems to support the concept that the 'spring' release occurs in the dark and the winding in the light since unhindered mechanical spring release is presumably more rapid than winding, which demands active energy input. If, however, in the future the converse proves to be true, botanists may possibly reach the conclusion that the designation 'sunflower' (of similar etymology in most languages) may be a misnomer and in its stead 'nightflower' may be suggested.

$$
\begin{aligned}
& \text { Yours faithfully, } \\
& \text { YA'ACOV Y. LESHEM }
\end{aligned}
$$

Bar-Ilan University,

Ramat-Gan, Israel

\section{'The Iron Sun'}

SIR,-Roman Znajek, in his review of my book The Iron Sun (30 June, page 867 ) suggested, no doubt unintentionally, that I had misquoted Einstein. In fact, I had made a proof-reading error. The passage in Einstein's The Meaning of Relativity to which I had wanted to draw attention is on page 26 of the 1973 Chapman and Hall Science Paperback edition. Yours faithfully,

London $W 8$ 